\title{
The Traveller Forum: An Advice-seeking Site Contributing to the Construction of Parental Social Actors and to On-line Parental Bond Creations*
}

\author{
Rosana Dolón \\ Department of English, University of Valencia, Valencia, Spain
}

\begin{abstract}
This paper studies how parental social actors and co-parental relationships are interactively constructed in traveller forums, analysing a corpus obtained from the London for Kids Trip Advisor forum, and carrying out a qualitative study of the interactants' uses of kids in their choice of transitivity patterns. Starting from a Critical Discourse Analytical methodological framework and from corpus-driven research, I address the question of how participants are endowed with authority and legitimation in parenting matters while engaged in this advice-seeking site. The results point at the emergence of inter-subjective role creations of parenting social actors, of instances of co-parental intrusion or complicity, whose legitimation and investment with authority often falls back on cultural and in general stereotypical presuppositions. The study is of interest for the tourist industry in general. Offering rich, authentic and often unsolicited customer feedback, forums are recognised to provide a cost-effective method to assess the quality of tourist services and consequently improve travellers' real demands. Through this research, the tourist industry may become aware of how parents construct and project themselves discursively as consumers of touristic services, and adapt these findings to their marketing interests..
\end{abstract}

Index Terms - critical discourse analysis, corpus study, traveller forum, inter-subjective discursive identity creation, social actor, collaborative web

\section{INTRODUCTION}

This article studies the discursive behaviour of participants in traveller forums. Among the rich variety of cybergenres, also known as internet, digital, virtual, electronic or web-based genres (see e.g., Shepherd \& Watters, 1998, 2004; Varga, 2011; Yus, 2001), the forum stands out for its important possibilities to intervene in an emergent collaborative web culture (Bruns, 2008): In the context of tourism, traveller forums offer particularly rich characteristics, supplying personal travel information, evaluations, analysis of customer preferences, an important variety of authentic and often unsolicited information (Bing et al., 2007), which promotional touristic genres in their marketing processes can importantly benefit from. The study of how parents through their interactive behaviour in forums construct a parental social actor for themselves and the other participating parents, offers the tourist industry an authentic characterization of the parents' identification both as a parent and as a touristic consumer that other promotional genres within the tourism industry can rely on for a more effective marketing activity.

\section{A. The Traveller Forum and Its Participation Framework}

The forum can be referred to as a task-oriented community (Porter, 2004), a site for interaction where the participants' communicative behaviour is not only geared towards an exchange of information, values and beliefs, but which does also conform to a transactional objective. There is an attempt to obtain - in any case complete - information that will eventually satisfy specific requests.

In the context of tourism, this participation framework often translates into travellers seeking advice on travel-related topics, which are addressed to a hypothetically expert audience, whose voluntary engagement in this web genre favours a dialectics of contrast, discussion and sometimes even contestation. As stated by Calvi (2010), we are in front of an informal genre, where "the tourist turns into an expert" (p. 23) while exchanging opinions and making evaluations. Anonymousness, the virtual location of the event, in fact the asynchronous nature of this computer mediated discourse behaviour, favours an interplay of support and sociability, endowing the threads with a sense of coherence and continuity (see e.g., Fayard \& De Sanctis, 2005; Herring, 2004, 2010; Yus, 2001; Santini, 2007; Shepherd, Watters \& Kennedy, 2004; Blanchard, 2004 for a detailed characterization). Yus (2001) would accordingly make reference to this

\footnotetext{
* This study has been carried out within a research Project granted and funded by the Spanish government (Ministry of Economy and Competitiveness, previously Ministry of Science and Innovation), Reference FFI2011-2472, Análisis léxico y discursivo de corpus paralelos y comparables (español, inglés y francés) de páginas electrónicas de promoción turística. 2011-2014.
} 
employing the concept of social glue, a characteristic that can be mapped onto that of discursive cohesion, to grasp the underlying conceptual bond between textual and social elements, tied together through criteria of shared and codependent meaningfulness, which participants create and maintain. Participants in forums also share a similar power status, which turns the genre into an important source of data. Being commercially unbiased, these data can be used by the tourism agents to know the real demands of tourists (Suau-Jiménez, 2014). Tourism web genres, which partake of the greatest hypertext so far, the World Wide Web, can be seen as multidimensional phenomena, where roles are easily exchanged as may easily overlap. Koskensalo (2012) talks about concepts such as prosumer, where the roles of producer and consumer blend, or that of produser, where the participant in the touristic discourse practice is producer and user at the same time. In traveller forums, parents engage both as consumers of touristic services but also as parents. While interacting in the forum, they address another hypothetically more expert tourist in travelling matters but also seek out the complicity or simply the voice of other people projecting themselves as parents.

\section{B. Aim of This Study}

As Thurlow and Jaworski (2011) observe, tourism is fundamentally semiotic in nature, and an intensely social business. It is interesting to highlight through this study how this touristic discourse practice shapes and projects parental social actors, as well as co-parental bonds.

The point of departure of the present study is to analyse the discursive construction of a social actor "parent" encoded through the use of the lemma kids according to specific choices made of transitivity patterns (Halliday, 1985) in the traveller forum (specifically, Trip Advisor). The paper attempts to disclose and produce an awareness of the parental social actors that are interactively constructed in this discourse practice. Taking into consideration tourism's powerful role in reshaping cultural practices and establishing ideologies of difference (Favero, 2007), the study may contribute to unveiling forms of projection of cultural presuppositions of parental legitimation or authorisation. The study seeks to reveal how participants are endowed with authority and legitimation in parenting matters.

The discursive creation of social actors is essential to our understanding of social interaction of all types, and calls forth concepts such as linguistic realization and emergence of personal agency, as well as that of inter-subjective discursive identity creation. As Al Zidjaly (2009: 178) points out, agency is "an interactive achievement" which can be referred to as "the socioculturally mediated capacity to act" or, as Van Leeuwen (2007) would phrase it, as how participants engage conversationally, legitimizing and/or endowing with authority their interactant's agentive role, thereby continually updating the projection of specific social actors in discourse behaviour.

Interactants engage in communicative behaviour, "deconstructing the participants into the social roles they undertake" (Al Zidjaly, 2009, p. 177) in accomplishing a task. This understanding of agency as a co-constructed and continually negotiated category requires an understanding of the discursive (re-)creation of identity in terms of an intersubjective activity. A dynamic approach to the concept of identity itself, which is understood as enclosing a meaning potential (Fairclough \& Wodak, 1997), which undergoes transformation in an interactive and reflexive social reality, where self-representation and projection is exposed to and contested by the self-representation and projection of the interactants. While projecting a specific social actor in one's communicative practice, the speaker does also partake of several role identities that he/she may consciously or inadvertedly embrace in the unfolding of the discourse behaviour. This viewpoint that draws on the principles underlying Interactional Sociolinguistics (e.g., Goffman, 1981), contributes to an understanding of a dynamic identity creation, with cultural frameworks and interpretative repertoires available to the participant, which will allow the interactant to align with, contest or resist specific stances of identity creation (see e.g., Hall, 1996; Wetherell \& Potter, 1988; Brubaker \& Cooper, 2000).

Dichotomizations of alignment, mostly drawn from the field of Social Psychology, contribute to an understanding of this dynamic approach to the discursive (re-)creation of social actors, where the interactant is understood to grasp different senses of the self, embracing invariably traits of a collective vs. personal identity, assimilating or differentiating him/herself from a role projection or excluding/including the self from a role representation. This interactive achievement has led linguists (e.g., Van Leeuwen, 1996) to conceive of a taxonomy of socio-semiotic categories in the creation of social actors and a corresponding proposal of linguistically encoded categories, which can be traced in the ensuing discourse practice, through the particular choices of lexical entries, syntactic patterns and attribution of semantic and pragmatic value.

It is important to note, as Heller (2003) would observe, that new information and service-based industries have led to the commodification of language and identity (see also Coupland (2007) for further discussion on language and identity being used as strategic styling resources). This is particularly the case of the tourist industry. Representations of identities, goods, places, abstract ideas, coveted aims, are integral to it. "Symbols, images, signs, phrases and narratives provide the ideas that fuel the commodification and consumption of tourist sites" (Hallett \& Kaplan-Weinger, 2010, p. 114).

This commodification practice, which the new media in general and specific formats in particular within the context of computer-mediated communication have largely encouraged and strengthened, endows tourism with a powerful role in reshaping cultural practices, establishing ideologies of difference, and perpetrating unequal relations of power, as Favero (2007) interestingly highlights.

\section{Methodology}


As mentioned before, I start from the assumption that the interactants who engage in the discursive activity of the traveller forum, besides embracing more or less expert versus lay social roles in touristic matters, do project and interactively negotiate and update parental social actor roles for themselves. At the same time they do also project a role-relationship, a continually negotiated parental bond between the intervening social actors. My research interest lies primarily in identifying the actual shape that the specific linguistic choices will unveil as regards this twofold role representation. I do, however, also question how far and in what ways the discourse practice renders examples of encoding of an identity "child" through the interactive construction of parental social actors and bonds.

\section{A. Research Framework}

For the present study I have relied on corpus-driven research as well as on the methodological framework of Critical Discourse Analysis (CDA). Within this broad interdisciplinary research framework I have used Van Leeuwen's (1996, 2007) Social Actor theory and applied Halliday’s (1985) transitivity system.

As to corpus-driven research, it provides the analyst both with a large-scale systematization of choices of patterns, and with an interesting tool for highlighting variation. Corpus methodologies prove interesting approaches when it comes to describing linguistic forms in context, their common collocates, as well as their distribution and variation patterns, (see e.g., McEnery \& Wilson, 1996; Baker, 2006; Stubbs, 2001; Partington, 2003). Baker (2006) adds an important observation when alluding to the potential of corpus studies to "uncover how language is employed, often in quite subtle ways, to reveal underlying discourses" (p. 13). This capacity for unravelling other underlying discourses is what Critical Discourse Analysis benefits from, as it draws on corpus methodologies. This field of research, as Fairclough (e.g. 1999) observes, aims to provide a framework for systematically linking properties of texts to features of their social and cultural circumstances. "Particular discursive events...are described in terms of the potentially innovative ways in which they draw upon the orders of discourse which condition them." (Fairclough, 1999, pp. 79-80). At the very heart of CDA lies an interest in uncovering ideological assumptions, hypothetical forms of bias, all of which start from a problematization of the discourse practice under study, a concept made salient by Foucault (1994). From the perspective of CDA, the very notion of identity is endowed with this problematization, where instances of imposed, recovered or conquered identity creations may be highlighted. This approach substitutes an essentialist view of identity for a dynamic category (see Grad \& Martín-Rojo, 2008, p. 23). Van Leeuwen's (1996) research in the field of CDA into the discursive creation of social actors shows that these socio-semantic representations are not conventionally tied to specific realizations. Rather, specific categories for the classification of social actors proved to be liable to the paralleled with specific choices at the level of syntax and lexis. His study allows us to consider specific lexico-grammatical patterns of choice potentially being mapped onto their correlating attribution of socio-semantic meaning.

Halliday's (1985) transitivity system proved to be an essential cornerstone to turn to, inasmuch as the components of participants, process and circumstances are integrated in the clause understood as a semantic representation of experience. This ideational meaning conceives of a framework that allows for the specific semantic projections of participant roles. From a critical discourse analytical perspective, Van Leeuwen's (1996) socio-semantic categorization for representational choices can well be mapped onto Halliday's grammatical categorization, where specific lexicogrammatical clause constructions can be paralleled with the identification of specific social actors, (re-) created and continuously updated in the discursive behaviour in forums.

\section{B. Material and Procedure}

For the present study I relied on a section of the corpus of our research team's database, the scope of which has been delimited according to criteria of corpus representativeness and validity. Of course, criteria of size and balance have also been attended to (see e.g., Atkins, Clear \& Ostler, 1992; Biber, 1995). This led me to a total of 189 complete threads retrieved from the travel forum Trip Advisor, more specifically from The Trip Advisor's forum London for Kids (http://www.tripadvisor.co.uk/SearchForums?q=London+for+kids) that is known to engage parents seeking for advice when travelling with their children. Every thread, variable in length, represents a complete interactive communicative event, inasmuch as it is framed by a marked initiation, when a participant joins the forum seeking to satisfy some request, and is terminated once all other prospective participants joining voluntarily to respond no longer engage in the interactive activity. These would yield a total amount of 136.256 words.

To prove my research objective, I carried out a qualitative analysis. A concordancing tool (AntConc3.2.) was used to trace systematic choices that could account for linguistic encodings of how parents negotiate and do interactively update their parental role. This was done considering parental role creations with respect to their children and in terms of coparental bonding between the intervening participants in the forum.

I needed the concordancing tool to identify occurrences of clauses with kids in subject position, which would allow me to identify through the choice of the transitivity patterns at issue, the discursive projections the parents make as to the participant roles for their children. To guarantee homogeneity of the corpus, it was important to restrict our samples to the encodings of the participant role of children to the form kids, as other word choices such as children, teens, boys, girls or their singular counterparts could have yielded different results. The decision of restricting this study to the form kids (the collective role representation) and hence exclude other forms for the representation of the social actor "child", as would typically be its singular form kid or the forms children or child, strictly obeys to reasons of scope of the present paper. 


\section{ANALYSIS AND RESUlTS}

Following our analysis, the most outstanding choice of representational process proved to be that of mental processes of affection, the parents projecting their children (kids, my kids, our kids) as Sensers. Some examples:

Kids absolutely loved Covent Garden

My kids love the London Aquarium

My kids loved it [Disneyland]

Our kids enjoyed [the Tower of London]

Both of our kids enjoyed Windsor

The kids like castles

\section{Kids really seemed to be having fun}

The kids like to see it [Madame Tussaud's]

Encoded in the verbs love, enjoy, like, the parents' clause construction places their children as agents of the expression of their own feelings and emotions. The use of past tense reinforces the fact of the feelings at issue having actually taken place and being recorded, there being proof of the enjoyment. Intensifiers, on the other hand (really, absolutely), do as well enhance the retrievable nature of the emotion. This unveils a strongly manifest parental presence: while placing their children as grammatical agents of these process representations, the parents do also legitimize themselves as omniscient knowers of their childrens' emotional experiences. It is interesting to note that the objects of these mental processes of affection are mostly names of so-called touristic icons, or also typically labelled "must-see" places such as Disneyland, London Aquarium, the Kew Garden, Covent Garden, Windsor, The Tower of London. The parental association as co-knower of the kids' emotional preferences seems to be restricted by the object of the affection, but it is also noteworthy that this bond excludes as well other mental processes such as cognition or perception, which are inexistent in the corpus.

A considerable amount of the mental affection processes enacted by the parents, with kids as grammatical agents, are framed by the use of the modal verbs might, would and will. Might being the most representative one (importantly outnumbering the uses with may), alludes to a parent who positions him/herself at a certain emotional distance from his/her children's perceptive role as Sensers, and hence also preferences in matter of tastes, tentatively referring to the children's objects of affection. These are here no longer names of touristic icons but names of other touristic places, noun or verb phrases which refer to specific activities. Some examples:

Kids might also enjoy a river cruise...

Kids might also enjoy a day walking the city walls

Kids might like a toy routemaster bus

Kids might like the ghost walks...

Kids might like to see that too [bike tricks]

It is interesting to observe, while considering the attitude markers through modality, that there is a very low number of uses with can, or could. As opposed to the scarce four examples found in our forum corpus, the choice with these modal verbs would be the most represented one in the corpus of touristic websites (see Dolón, 2012), endowing the kids with the agentive role of somebody with possibilities of choice.

Kids can catch a glimpse

Kids can enjoy some attractions

Kids can sit (outside) with you

Kids could see the active volcano

This infrequent, scarce choice (no matter the clause representation at issue) may convey the parental recreation, shared by the other parent participants to the forum, of a social actor kids that is devoid of any power of decision or choice.

While the first mentioned examples of mental processes of affection without modal pre-modification made often reference to recorded experiences in the past, projected hence as 'proved', the uses with will represent counterpart processes, looking instead into the future in its non-specific scope of embracing meanings of hypothesizing and promising. Some examples:

Kids will simply LOVE the bus and tube system

If your kids will enjoy the underground tour

Your kids will have a ball - mine loved using the underground

Your kids will like it

The kids will love gifts from Hamley's

Kids will love Disneyland

Kids will love the sleeper [train]

This prospective representation endowed with a sense of promise and truth value seems to convey the same associative function where the parent closes in on the child in his/her role as Senser, the modal verb will reinforcing the parents' authority to ascertain his/her child's affectionate perceptions. It is interesting to point out that these processes are constructed along generic representations of the agentive role kids, in all cases used without determiner, as opposed 
to the counterpart examples of parents reporting a past, consumed mental experience, projecting a specification of kids, identified with the article or possessive adjective: the kids, my kids, our kids, both of our kids.

As opposed to the uses with might and will, the first set projecting touristic activities encoded in noun phrases or other clauses, the latter highlighting singled out nominal concepts standing for elements of appeal (e.g.: gifts, the sleeper train, Disneyland), the uses with would turn out to reveal choices of more specific nature. Some examples:

Your kids would love the sharks

The kids would love the lights

The kids would like to be near a beach

This conditional meaning draws on a parental role representation that is tentative in its counseling function coinciding with explicit reference to the other parents and to non-stereotypical choices.

It is also interesting to note that the most abundant clause representation recreating mental processes of affection, does mainly rely on the verbs love, like and enjoy, while verbs of volition are only scarcely being used. In fact, only three examples could be traced:

My kids very much want to visit an awesome castle

6 adults and 2 kids wanna take in London for a day

(if) the kids want punting, consider Cambridge

This again reinforces the idea of the parents' insistence on portraying a representational discourse identity of their kids in forums in terms of Sensers.

Examples of clauses of mental affectionate perception with kids (with or without pre-modification) in grammatical position of agent are on average four times more frequent than those where the parent places him/herself as the subject of a clause of mental cognitive perception, framing its subsequent subordinate clause with kids being again the agent of a mental process of affectionate perception. Some examples:

I think your kids will be interested in 2-3 hour tour

I think the kids will be free

I think my kids will find that stuff very cool

I'm not sure if my kids will like the Tower of London

I think kids would like those

I think that most kids would like it

This subset, in spite of its low frequency in occurrences, represents an explicit grammatical encoding of emotional detachment on the part of the parent, hedging the children's affectionate choices through epistemic verbs. It is also in these uses that the kids are referred to not generically but singled out through determiners that range from defining article, quantifications, to possessive adjectives in most cases.

While it is true that the vast majority of examples of representative choices rely on mental processes of affectionate perception, examples of material, behavioural and verbal processes could also be identified. Some examples:

\section{Material processes:}

Kids eat breakfast for free.

and kids eat for free.

Kids have breakfast included.

The kids had fish and chips.

Behavioural processes:

The kids get too tired.

Kids over 11 are likely to get bored silly by Legoland

Kids give up after 3-4 hours (to make the castle too).

So kids sleep [with overnight flights]

Mental processes:

My adult kids have heard bad things about safety in this area. (perception)

My kids have seen the travelling exhibition of King Tut's (perception)

If your kids have watched Hunchback of Notre Dame (perception)

(you) will have kids have your thought about Disneyland Paris? (cognition)

\section{Verbal processes:}

My kids have been asking to go to a show.

Material processes situate kids as engaged actors involved in their own doings. Interestingly enough, most examples are related to eating, which alludes to a low degree of parental intrusion on the kids' activity arena, this being furthermore restricted to matters of food consumption. More instances can be found of behavioural processes drawing on stereotypical 'unmarked' travelling behavior. Verbal processes constitute rare occurrences with only one example being traced. This contributes to the discursive creation of a parental social actor in traveler forums as depriving his/her child from authority in terms of having a saying, a voice that is being listened to. As Van Leeuwen (2007, p. 94) points out referring to Halliday (1985), personal authority legitimation takes the form of a verbal process clause, very often recreated in issues related to parental or teacher authority. 
The large body of corpus samples representing processes of affection, with kids loving, liking, enjoying, contrasts with but a few examples of kids being the agents of mental processes of perception (watch, see, hear) and just a single case of cognition (have your thought). Parents seem to feel entitled to interact in travel forums enacting their children's agentive role principally in their social role as Sensers, and minimally projecting them in their cognitive role as Thinkers.

A different section of samples comprises forms of relational process types. This representational choice may establish relationships of sameness, when two identities are equaled, define an entity in terms of location, time and manner (circumstantial process) or indicate ownership (Halliday, 1985). Van Leeuwen (1996, p. 54) hints at the underlying potential of relational processes for the legitimation of social actors and their practices in discursive behaviour. Hence, they constitute an important element of analysis. All the samples of the corpus were found to recreate patterns of sameness. On the one hand, identification was represented alongside issues of age. Some examples:

Your kids are not of the age [stay in rooms by themselves]

My kids were younger

The kids are older now

The kids were very young

These are important, inasmuch as their use complies with the generic nature of the traveller forum, initially framed as child-oriented where it makes perfect sense to exchange information whose content will very much depend on the variable of age.

Another series is made up of evaluative adjectives or evaluative comments. Some of these highlight the childrens' tastes and preferences. Some examples:

Kids are huge fans of...

My kids are very picky

If your kids are into the movie

Your kids are not into museums

The kids were lukewarm about the idea of...

The semantic characteristics that are made salient range from acceptance, refusal to neutrality, avoiding lexical entries that would recreate strong emotional involvement on the part of the parent or over-specification. Yet a third group implies a stronger intrusion on the part of the parent, whose projection of relational clauses conceives of the identification of the kids with adjectives or nouns of evaluative nature, invoking issues of endurance, traveller knowhow and so-called proper behaviour. Some examples:

My kids were complete troopers

My kids are good travelers

The kids are actually pretty good [not cranky]

Your kids are good in crowds

Remember the kids sometimes are cranky

These uses draw on presuppositions of moral standing, where a child deserving the label of good traveller has to comply with underlying traditional values of not complaining and following the pace and rhythm 'imposed' by their parents. This type of legitimation may have a 'naturalizing effect' (Van Leeuwen, 2007, p. 99) leading to an unquestioned acceptance of truth values traditionally associated with it.

Legitimation of social practices may be realized through purpose constructions, containing an activity, a purpose link and the purpose itself." (Van Leeuwen, 2007, pp. 100-103). Some examples:

Visit Louvre for your kids to find out where is Mona Lisa

(A ball is a cheap way) for kids to flock to other kids

(...old ruins) for the kids to run around in

(...great views and room) for the kids to wander

They've a playhouse for kids to spend some jolly good time

While our samples do not seem to rely on elements of moralization, it is worth looking into their use inasmuch as they are examples of instrumental rationalization, and as such "... are constructed in discourse in order to explain why social practices exist, and why they take the forms they do." (Van Leeuwen, 2011, p. 101). Interestingly enough, the activity that is highlighted in our examples takes the shape of material process representation. This invokes traditionally accepted values that stereotype healthy child behaviour as related to physical activity (wander, run around), their natural appeal to be with other kids (kids flock to other kids), a natural interest in playing (spend some jolly good time), and a need for experimentation along an impulse to satisfy their curiosity (find out where Mona Lisa is).

In our corpus, with kids in subject position, parents have proved to introduce their children into the forum dynamics in terms of the kids (definite article), zero modifier (kids) or possessive adjective (my, our kids). These being the most common choices, which do either project a generic label for kids or a sense of belonging with respect to the parents, there are other uses which identify kids relying on defining relative clauses, which have an interesting selection and grouping effect. Some examples:

Kids who are too young to stay out late,

Kids who can of course get involved themselves, 
Kids who don't spend too much time in cathedrals,

Kids who enjoy a train ride more than flights,

Kids who like Harry Potter,

Through this choice, the parent alludes to the other parents' shared set of presuppositions, which hold for grouping their children under a label that would comprise a set of preferences in tastes or natural inclinations, which will eventually guarantee that the appropriate target group of children is being addressed while giving advice about what to do with his/her kids. In spite of their low occurrence, these examples reveal an interesting example of parental bonding in the forum, based on a sense of complicity around shared presupposed knowledge.

So far, parental bonding in the interactive engagement in our traveller forums proved to rely primarily on representational clause structures where the social actor kids stands in agentive position. These choices do importantly outnumber those where kids is put forward in a beneficiary participant function onto whom the process is projected. While these do barely represent $18 \%$ of the corpus, they are important to take into consideration, as they allow for revelation of what the parents in their interactive behaviour conceive of elements to affect and have an effect on their children. The most frequent pattern recreates a clause representation where kids is the direct object of a parental social actor encoded in a material process. This is furthermore exclusively expressed through the verb choices of bringing and taking. Some examples:

I'm bringing my three kids to London

I brought my kids to London

I also want to take my kids to watch Harry Potter

I have taken kids of all ages into London

Four further examples recreate patterns of kids in circumstantial position, to whom the touristic service in terms of a realizable activity or enjoyable touristic place is addressed:

(Chessington World of Adventures) is more focused at kids

(Blenheim Palace) aimed specifically at kids

Interactive displays that are geared towards kids

The place is very much geared towards kids

A specific set of uses is worth highlighting inasmuch as the participant parent explicitly interacts with other parents relying on a syntactic structure of appeal, encouraging or urging the other parents to carry out certain actions getting their children involved. These are imperative structures with direct appeal to an implicit you-subject:

have a look at the kids section in TimeOut London

bring the kids, they'll love the experience

give at least a day for the kids to work through some of the jet lag

[at British Museum] be sure to get the kids audio visual trail

let your kids feed the ducks in St James Park

take the kids punting at Cherwell Boathouse

These uses are of great interest, as they express a high degree of intrusion onto the other peers' parenting arena, the semantic representation of experience being assumed as legitimate in this type of parental bonding. As the examples show, in addition to the most frequent choice, which translates in terms of making the kids access a pleasurable experience (e.g. bring, see to take, get to look, get our kids, take the kids...), there are also uses that invoke authority, the parent at issue requesting permissiveness on the part of his/her peer interactant (let your kids...). Recreating the same intentionality, two uses, with kids in agentive grammatical position, also exemplify a strong co-parental intrusion, imposing courses of action to be taken with respect to the raising of their kids:

Kids should get out and travel and experience...

Kids need breaks from museums

\section{DISCUSSION AND CONCLUSION}

The qualitative analysis of our corpus has provided us with interesting insights. Not only specifically about how the participants' engagement in the traveller forum reveals an interactively negotiated (re-) creation of a parenting role that starts on the one hand from the parent-child relationship and on the other hand from the parent-parent bonding. We have also managed to access the ways in which this participation framework in the context of the tourist industry sheds light on the nature of the forum as an advice-seeking site.

Only $18 \%$ of the uses were found with kids being the beneficiary participant role projected by the parents' contributions, as opposed to $82 \%$ with kids representing the agent of the process. These few occurrences with kids in beneficiary position do mostly recreate a role representation of the parents as actors involved in material processes, where the process translates in terms of taking and bringing the children to one place or other. This can be fundamentally referred to as an instrumental role that the parent projects with respect to the children. The other subset within this $18 \%$ samples, is mostly made up of process type representations which mean a strong co-parenting intrusion on the part of a parent into the other parents' arena of parental responsibilities. We are talking here of imperative structures highlighted before, where one parent explicitly encourages or even urges the other parent to carry out certain actions (e.g.: bring the kids, let the kids, take the kids). However strong this intrusion may be conceived of, it does not 
draw on moralizing precepts, the co-parental intrusion being rather based on discrete tips where complicity can be presupposed.

On the other hand, $82 \%$ of the uses do start from kids in subject position, the most outstanding representational process being that of mental affection. These uses (kids enjoy, kids like,...) while recreating a social actor role for the child as agent of his/her own perception of feelings and emotions, do nonetheless convey a strong parental presence inasmuch as the parent legitimizes him/herself for talking on behalf of their children in matters that concern their offspring's feelings. While it is true that a few examples with kids being projected as Sensers is framed by the parents in subject position in the participant role of cognitive perceivers (I think the kids..., I believe the kids...) this emotional detachment on the part of the parent is only apparent, since these uses conform to a mere fifth part of the samples identified.

It is noteworthy at this stage to highlight the total lack of other mental processes with kids in subject position. While the children's projection as Sensers is the most frequent one, the parents while participating in the forum do not endow their children in their representational choices as agents of their own cognitions or perceptions, making them devoid of this agentive trait. The parents put forward an agentive role for their children when it comes to liking or enjoying touristic services, but not when it comes to cognitively evaluating these.

Another interesting observation makes reference to the few examples of kids represented by their parents as Doers in material processes or as Sayers in verbal processes. If we add to this that the few material processes mentioned revolve all around eating matters, we can conclude that the parents project a social role of their children as non-engaged in their own doings.

Relational processes, on the other hand, do again point to specific co-parental bond creations inasmuch as they allow the projection of evaluative expressions (the kids are...). Aside from the examples found in the corpus where relational processes simply obeyed the exchange of practical information (questions of age), we found important examples of coparenting intrusion. These were typically found to recreate issues of children endurance, traveller know-how, the children's tastes and preferences. They were also found to draw on presuppositions of moral standing, and fall back on the compliance with underlying traditional values of what counts as being a good traveller. These uses have a naturalizing effect, where participating parents are led to start from a truth-value traditionally and culturally assigned to them.

Despite this moral standing that might be highlighted, none of the representational choices could be said to have a moralizing effect or purpose in the interactive behaviour. Even in the purpose constructions, which were found to project an activity advisable for the kids to be carried out, these invoke traditionally accepted values that call forth stereotypical healthy child behaviour (the children's inclination to play with other kids, to satisfy their curiosity, to develop a natural interest in playing).

To further summarise our findings, we can say that parents project, while engaged in the forum's interactive activity, a parental bond with their children that turns these into agents of their feelings and emotions as the most outstanding social role (that is Sensers, as opposed to Thinkers, Doers, Speakers or Perceivers). On the other hand, they feel entitled to speak on behalf of their children's emotions, something which does as well deprive them from any agentive status.

In addition to these, co-parenting representations could also be highlighted, where the participants intrude on their parent counterpart's arena, intervening in a more or less direct way in the parenting tasks. This was found to be especially articulated through allusion to other parents' shared set of presuppositions: Drawing on traditionally accepted evaluations for what counts or not as being a good travelling behaviour for kids, such as keeping up with the parents' pace, not complaining and others mentioned before. Another way of articulating this co-parenting was accounting for allusions to presuppositions related to natural child behaviour, invoking character traits that are culturally and stereotypically related to "normal" child behaviour, as is the child's natural appeal to physical activity, to the need for experimenting, to play with other kids or to satisfy their curiosity. The strongest forms of intrusion having been traced are the direct appeals to the other parents to carry out certain activities with their respective kids, using imperative structures. This discursive behaviour was also found to rely on stereotypical actions (let your kids decide, leave the kids with grandparents). What is interesting about these representational choices is that they mark instances of complicity rather than representing any patronising behaviour.

These findings are also interesting when we consider these representations across different touristic genres, where the projection of parental and co-parental social actors in the discursive behaviour is based on different constructions. This is the case, for example, of the study of webpages, where the discourse practice was found to recreate a social actor parent that differs importantly from this genre (see Dolón, 2012).

It would be of great interest to continue studying these representations in travel brochures, travel guides, guidebooks, travelogues, and other touristic genres to unveil forms of discursive creation of parental roles and bonds. Given the fact that these often rely, as shown in this study, on cultural presuppositions, stereotypes or discursive creations of roles and forms of authority and legitimation, they may well deserve revisiting to consider, if it is the case, alternative emancipatory forms of discursive behaviour.

These types of study can have important implications for the tourist industry. This is especially the case when we look into promotional touristic genres that have a highly persuasive component in the discourse practice, such as hospitality websites (hotels, restaurants, etc.) or touristic guides. As was proved before (see Dolón, 2012) official tourist 
websites, for example, project a social actor parent with importantly biased stereotypical presuppositions that do frequently not coincide and often clash with the social actors parents construct themselves in forums. Thus, the tourist industry should be aware of how parents construct and project themselves linguistically through the traveller forums and integrate these discursive practices into their own promotional discourse cross-generically, especially in those genres being addressed to family tourism, in order to adapt them to their marketing interests.

\section{ACKNOWLEDGMENT}

My acknowledgements to the members of our research project COMETVAL, based in the Facultat de Filologia, Traducció I Comunicació in Valencia, who are all engaged in the creation of a database of tourism web genres.

\section{REFERENCES}

[1] Al Zidjaly, N. (2009). Agency as an interactive achievement. Language in Society 38, 177-200.

[2] Anthony, L. (2011). AntConc 3.2.4w [Computer Software]. Tokyo, Japan: Waseda University.

[3] Atkins, S., J. Clear \& N. Ostler (1992). Corpus design criteria. Literary and Linguistic Computing 7(1), 1-16.

[4] Baker, P. (2006). Using corpora in discourse analysis. London: Continuum.

[5] Biber, D. (1995). Dimensions of register variation: A cross-linguistic comparison. Cambridge: Cambridge University Press.

[6] Bing, P., T. MacLaurin \& J.C. Crotts (2007). Travel blogs and the implications for destination marketing. Journal of Travel Research 46(1), 35-45.

[7] Bruns, A. (2008). Blogs, wikipedia, second life, and beyond. Frankfurt: Peter Lang Publishings.

[8] Blanchard, A. (2004). Virtual behavior settings: An application of behavior setting theories to virtual communities. Journal of Computer-Mediated Communication 9:00. doi: 10.1111/j.1083-6101.2004.tb00285.x.

[9] Brubaker, R. \& F. Cooper (2000). Beyond 'identity'. Theory and Society 29, 1-47.

[10] Calvi, M.V. (2010). Los géneros discursivos en la lengua del turismo: una propuesta de clasificación. Ibérica 19, 9-32.

[11] Coupland, N. (2007). Style. Language variation and identity. Cambridge: Cambridge University Press.

[12] Crystal, D. (2006). Language and the internet. Cambridge: Cambridge University Press.

[13] Dolón, D. (2012). El niño como actor social en el discurso turístico: un estudio de análisis crítico de la construcción discursiva de una identidad de consumidor. J. Sanmartín (ed.), Discurso Turístico e Internet. Madrid: Iberoamericana, 155-186.

[14] Fairclough, N. (1992). Discourse and social change. Cambridge: Polity Press.

[15] Fairclough, N. (1999). Global capitalism and critical awareness of language. Language Awareness 8(2), 71-83.

[16] Fairclough, N. (2002). Analysing discourse. Textual analysis for social research. London: Routledge.

[17] Fairclough, N. \& R. Wodak. (1997). Critical discourse analysis. In T.A. van Dijk (ed.), Introduction to Discourse Analysis. London: Sage, 258-284.

[18] Favero, P. (2007). What a wonderful world!: On the touristic ways of seeing, the knowledge and the politics of the culture industries of otherness. Tourist Studies 7(1), 51-81.

[19] Fayard, A.L. \& G. DeSanctis. (2005). Evolution of an online forum for knowledge management professionals: A language game analysis. Journal of Computer Mediated Communication 10(4): article 2. http://onlinelibrary.wiley.com/doi/10.1111/j.1083-6101.2005.tb00265.x/full. (accessed 17/5/2014).

[20] Foucault, M. (1994). Le souci de la vérité. In D. Defert \& F. Ewald (eds.), Dits et Ecrits (vol.4). Paris: Gallimard, 668-678.

[21] Goffman, E. (1981). Forms of talk. Philadelphia: University of Pennsylvania Press.

[22] Grad, H. \& L. Martín-Rojo (2008). Identities in discourse. In R. Dolón \& J. Todolí (eds.), Analysing identities in discourse. Amsterdam: John Benjamins Publishing Company, 3-30.

[23] Hall, S. (1996). Introduction: who needs identity? In S. Hall \& P. du Gay (eds.), Questions of cultural identity. London: Sage, $1-17$.

[24] Halliday, M.A.K. (1985). An introduction to functional grammar. London: Edward Arnold.

[25] Hallett, R.W. \& J. Kaplan-Weinger (2010). Official tourism websites. A discourse analysis perspective. Bristol: Channel Publications.

[26] Heller, M. (2003). Globalization, the new economy and the commodification of language and identity. Journal of Sociolinguistics 7, 473-498.

[27] Herring, S. (ed.) (1996). Computer-mediated communication. Linguistic, social and cross-cultural perspectives. Amsterdam/Philadelphia: John Benjamins.

[28] Herring, S. (2004). Slouching toward the ordinary: current trends in computer-mediated communication. New Media \& Society 6(1), 26-36.

[29] Herring, S. (2010). “Computer-mediated conversation: introduction and overview”. Language@ Internet 7, 1-12.

[30] Marcoccia, M. (2004). On-line polylogues: conversation structure and participation framework in internet newsgroups. Journal of Pragmatics 36, 115-145.

[31] McEnery, T. \& A. Wilson, A. (1996). Corpus linguistics. Edinburgh: Edinburgh University Press.

[32] Partington, A. (2003). Wordings of war: Corpus-assisted discourse studies on the Iraq war. London: Routledge.

[33] Porter, C.E. (2004). A typology of virtual communities: A multi-disciplinary foundation for future research. Journal of Computer-Mediated Communication 10(1), 00. http://onlinelibrary.wiley.com/doi/10.1111/j.1083-6101.2004.tb00228.x/full. (accessed 17/5/2014).

[34] Santini, M. (2007). Characterizing genres of web pages: genre hybridism and individualization. In Proceedings of the 40th Annual Hawaii International Conference on System Sciences, p. 71.

[35] Shepherd, M., C. Watters \& A. Kennedy (2004). Cybergenre: automatic identification of home pages on the web. Journal of Web Engineering 3(4), 236-251. 
[36] Stubbs, M. (2001). Texts, corpora, and problems of interpretation: a response to Widdowson. Applied Linguistics 22(2), 149172.

[37] Suau-Jiménez, F. (2012). Páginas web institucionales de promoción turística: el uso metadiscursivo interpersonal en inglés y español. In J. Sanmartín Sáez (ed.), Discurso turístico e internet. Madrid: Iberoamericana/Vervuert, 125-154.

[38] Suau-Jiménez, F. (2014) Dialogic voices of writers and readers in traveller forums through interpersonality. In L. Gil Salom \& C. Soler Monreal (eds.), Voices and dialogic engagement in written specialised genres. Amsterdam: John Benjamins. (in press)

[39] Swales, J. (1990). Genre analysis. Cambridge: Cambridge University Press.

[40] Thurlow, C. (2001). The internet and language. In R. Mesthrie (ed.), The concise encyclopedia of sociolinguistics. London: Pergamon, 287-289.

[41] Thurlow, C. \& A. Jaworski (2011). Tourism discourse: languages and banal globalization. Applied Linguistics Review 2, 285312.

[42] Van Leeuwen, T. (1996). The representation of social actors. In R. Caldas-Coulthard \& M. Coulthard (eds.), Texts and Practice. London: Routledge, 32-70.

[43] Van Leeuwen, T. (2007). Legitimation in discourse and communication. Discourse and Communication 1(1), 91-112.

[44] Varga, C. (2011). Knowledge transmission in cyberspace. Ph.D. Dissertation. Universitat Pompeu Fabra. http://www.tdx.cat/bitstream/handle/10803/24900/tcv.pdf?sequence=1 . (accessed 17/5/2014).

[45] Wetherell, M. \& J. Potter. (1988). Discourse analysis and the identification of interpretative repertoires. In C. Antaki (ed.), Analysing Everyday Explanation: A Casebook of Methods. London: Sage, 168-183.

[46] Yus, F. (2001). Ciberpragmática. El uso del lenguaje en internet. Barcelona: Ariel Lingüística.

Rosana Dolón is Associate Professor of English Language and Linguistics Studies in the English Department at the University of Valencia, Spain. She teaches and researches in the areas of Discourse Analysis, English in specialized genres and English as a Foreign Language. 